phosphate is much superior to other phosphatase substrates.

The medium consists of nutrient agar to which is added a sterile solution of disodium $p$-nitrophenyl phosphate. This medium is used in the normal way. The streaked Petri dishes are examined after 24-hr. incubation at $37^{\circ} \mathrm{C}$. and the presence of phosphatase is indicated by the yellow colour of liberated $p$-nitrophenol surrounding colonies of $M$. pyogenes var. aureus. Positive results are readily discernible after 16-18-hr. incubation.

The incorporation of high concentrations of sodium chloride in the media has only a slightly inhibiting effect on phosphatase production. This effect is less than the inhibition caused by sodium chloride in $\mathbf{a}$ medium using phenolphthalein phosphate as substrate $^{1}$, probably because of the high sensitivity of the disodium $p$-nitrophenylphosphate ${ }^{5}$.

Investigations are proceeding to determine the optimal level of substrate concentration and to examine the incorporation of inhibiting agents for Gramnegative organisms.

Fisons Milk Products, Ltd., Coleraine.

Jan. 7.

${ }^{1}$ Barber, Mary, Brookbank, B. W. L., and Kuper, S. W. A., J. Path Bact., 63, 57 (1951).

${ }^{2}$ Barber, Mary, and Kuper, S. W. A., J. Path. Bact., 63, 65 (1951).

${ }^{3}$ Walder, Winifred O., Lab. Practice, 2, 419 (1953).

- Barnes, Ervine, H., and Morris, James F., J. Bact., 73, 100 (1957)

Bessey, 0. A., Lowry, O. A., and Brock, M. J., J. Biol. Chem., 164, 321 (1946).

\section{Metabolic Role of Xanthopterin}

AlberT ${ }^{1}$ has suggested that xanthopterin would be found in higher amounts in neoplastic tissues than in normal. In anticipation of confirming this by direct experiment, we have analysed for their pterin content, normal kidney tissue of the golden hamster and transplantable neoplasms in the golden hamster, derived from stilbostrol-induced renal tumours ${ }^{2}$. No xanthopterin could be found. The largest amount of tissue used was $1 \mathrm{gm}$. of normal tissue and $8 \mathrm{gm}$. of neoplastic tissue, and the smallest amount of xanthopterin that could be detected by the paper chromatographic technique used was $0 \cdot 1 \mu \mathrm{gm}$.

Xanthopterin has been isolated from human urine $^{3}$. If, however, xanthopterin is present as a tissue metabolite, some of it should be oxidized to leucopterin by xanthine oxidase ${ }^{4}$. This expectation is borne out by the occurrence of leucopterin in the kidney tubules of golden hamsters given massive doses of xanthopterin ${ }^{5}$. An analysis of human urine failed to reveal leucopterin (which would have been found between the origin and 2-amino-4-hydroxypteridine-6-carboxylic acid in the propanol-5 per cent aqueous acetic acid $(2: 1 \mathrm{v} / \mathrm{v})$ solvent system used) $)^{6}$.

Kalckar et $a l .^{7}$ found that xanthopterin was not present in freshly voided urine, but that a colourless non-fluorescent substance was present which was converted to xanthopterin by air oxidation. Futterman and Silverman ${ }^{8}$ found $a$ labile substance in human urine the properties of which resembled an unformylated reduced folic acid, and Blakley' has demonstrated that di- and tetra-hydrofolic acids are readily oxidized to xanthopterin.

Slavik et al. ${ }^{10}$ found xanthopterin in the urine of rats fed tetrahydrofolic acid but showed that the xanthopterin was formed during isolation by the non-enzymic oxidation of tetrahydrofolic acid.

The present burden of evidence is therefore that xanthopterin is absent from mammalian tissues. The biological effects of xanthopterin in mammals should therefore be attributed only to the disturbance of a normal metabolic pathway by an artificially introduced substance.

A fuller account of this work will be published elsewhere in due course.

We wish to thank the Chemical Society for a grant in aid of this investigation, and Prof. A. C. Haddow and the Chester Beatty Research Institute for the supply of normal hamsters and hamsters with tumours.

\section{University College of Ghana,}

\section{J. A. Blair} Achimota, Ghana.

1 Albert, A., Biochem. J., 65, 124 (1957); 57, x (1954).

${ }^{2}$ Horning, E. S., Z. Krebsforschung, 61, 1 (1956).

' Koschara, W., Hoppe Seylers Z., 240, 127 (1936).

4 Wieland, H., and Liebig, R.. Ann., 555, 146 (1944). Kalckar, H. M. Kjeldgaard, N. O., and Klenow, H., Biochim. Biophys. Acta, 5 $575(1950)$. 5 Haddow, A. C. "Chemistry and Blology of Pteridines", 101 (J. and
A. Churchili, London, 1954).

- Blair, J. A., Biochem. $J$. (in the press).

" Kalckar, H. M., Floystrup, T., and Schou, M., Proc. 1st Internat. Congr. Biochem., $75(1949)$. Floystrup, T., Schou, M., and KalCongr. Biochem., 75 (1949). Floystrup, T., Scho
ckar, H. M., Acta Chem. Scand., 3, 985 (1949).

Futterman, S., and Silverman, M., J. Biol. Chem., 224, 31 (1957).

Blakley, R. L., Biochem. J., 65, 331 (1957).

${ }^{10}$ Slavik, K., Dvorakova, A., and Slavikova, V., Chem. listy, 51, 1536 (1957).

\section{Chromatographic Separation of Lactalbumin from Human Milk Whey on Calcium Phosphate Columns}

According to Deutsch ${ }^{1}$ and Wegelin ${ }^{2}$ bovine and human milk wheys differ to a certain extent in electrophoretic patterns. On the basis of paper electrophoretic data, Fontaine ${ }^{3}$ considers it probable that the electrophoretic fractions in human milk whey closely correspond to different proteins found in bovine whey (serum albumin, $\beta$-lactoglobulin, $\alpha$-lactalbumin and immune globulins). As part of an investigation of the protein composition of human milk whey and its relation to bovine whey, I have studied the separation of a crude 'albumin'-fraction from human milk by means of chromatography on calcium phosphate.

Pooled, frozen human milk or fresh milk was used. After defatting the milk by centrifugation, the lactalbumin fraction was obtained by salting out with ammonium sulphate in the following way. A crude fraction consisting of casein and lactoglobulins was removed at 50 per cent saturation. The lactalbumin fraction was then precipitated by saturating the remaining solution with ammonium sulphate. This crude albumin consisted of three main components judging by paper electrophoresis (Fig. 1).

The calcium phosphate gel was prepared according to Tiselius ${ }^{4}$. 250-mgm. samples of lyophilized protein were dissolved in $10 \mathrm{ml} .0 .03 M$ sodium phosphate buffer $p H \quad 6 \cdot 9$, containing $0 \cdot 1 \quad M$ sodium chloride. This solution was applied to calcium phosphate columns, $2 \cdot 8 \mathrm{~cm} . \times 8 \mathrm{~cm}$., previously washed with the same buffer solution. Elution was performed with a slight external pressure giving a flow-rate of approximately $20 \mathrm{ml} . / \mathrm{hr}$. The effluent was collected in $5 \cdot \mathrm{ml}$. fractions and the protein concentration of each 